\title{
PENGARUH APLIKASI CAHAYA TERHADAP SPERMATOZOA MENCIT JANTAN (MUS MUSCULUS L)
}

\author{
${ }^{1}$ Junita Iriandini \\ ${ }^{2}$ Lydia Tendean \\ ${ }^{2}$ Benny Wantouw
}

\author{
${ }^{1}$ Kandidat skripsi Fakultas Kedokteran Universitas Sam Ratulang Manado \\ ${ }^{2}$ Bagian Biologi Universitas Sam Ratulangi Manado \\ Email: junitairiandini@ymail.com
}

\begin{abstract}
Light as a form of physical and psychological stress responses activated central and peripheral endocrine system in general interfere with the process of spermatogenesis especially the quantity and quality of the sperm of mice consisted of concentration, morphology and motility. The purpose of this study was to determine the effect of the application of the quality of light as well as the mechanism of spermatozoa of mice. Experimental studies with a completely randomized design done in November and December 2012 using 27 mice as a sample for 30 days, each consist of nine mice as a control, nine mice were given 4 lamp light exposure (12 volts) and 9 others mice were given a presentation by 8 light exposure (24 volt). The results of this study found that the percentage of motility in the first nine treated mice by $25.22 \%$ abnormal and in the second treatment $35.66 \%$ were abnormal; concentration of spermatozoa in the first treatment were $7.43 \times 10^{5}$ abnormal and the second treatment $6.45 \times 10^{5}$ were abnormal; morphology of spermatozoa in the first treatment were $57.88 \%$ abnormal and $67.22 \%$ abnormal in the second treatment. The conclusion of this study found that the provision of light affect the quality of spermatozoa of mice include motility, morphology, concentration; and the higher the light application, the lower the quality spermatozoa in mice will be.
\end{abstract}

Keywords: Light, Stress, Spermatozoa Quality of mice

\begin{abstract}
Abstrak: Cahaya merupakan bentuk stress fisik dan psikologis mengaktifkan respon sentral dan perifer sistem endokrin yang secara umum mengganggu proses spermatogenesis khususnya terhadap kuantitas dan kualitas spermatozoa mencit terdiri dari konsentrasi, morfologi dan motilitas. Tujuan dari penelitian ini adalah untuk mengetahui pengaruh aplikasi cahaya serta mekanismenya terhadap kualitas spermatozoa mencit. Penelitian eksperimental dengan rancangan acak lengkap di lakukan pada bulan November sampai Desember 2012 dengan menggunakan sampel sebanyak 27 ekor mencit selama 30 hari, masing-masing terdiri dari 9 ekor mencit sebagai kontrol, 9 mencit di beri pemaparan cahaya sebanyak 4 lampu (12 volt) dan 9 mencit lainnya di beri pemaparan cahaya sebanyak 8 lampu (24 volt). Hasil dari peneltian ini didapatkan persentase motilitas pada 9 mencit perlakuan pertama sebesar 25,22\% abnormal dan pada perlakuan kedua 35,66\% abnormal, konsentrasi spermatozoa pada perlakukan pertama $7,43 \times 10^{5}$ abnormal dan pada perlakuan kedua $6,45 \times 10^{5}$ abnormal, morfologi spermatozoa pada perlakukan pertama 57,88\% abnormal dan pada perlakuan kedua 67,22\% abnormal. Kesimpulan dari penelitian ini didapatkan bahwa pemberian cahaya lampu berpengaruh terhadap kualitas spermatozoa mencit dalam hal ini motilitas, morfologi, konsentrasi dan semakin aplikasi cahaya di naikkan maka kualitas spermatozoa mencit akan menurun.
\end{abstract}

Kata kunci : Cahaya, Stres, Kualitas Spermatozoa mencit. 
Kualitas spermatozoa terdiri dari motilitas, konsentrasi dan morfologi. Motilitas spermatozoa adalah kemampuan spermatozoa dalam bergerak maju dengan secara progresif, konsentrasi spermatozoa normal bila $\geq 15$ juta/ml, dan morfologi spermatozoa kepala berbentuk oval dan mempunyai ekor yang panjang sekitar 3-5 mikron.-3 Spermatozoa mencit adalah sel kelamin (gamet) yang diproduksi di dalam tubulus seminiferus melalui proses spermatogenesis, dan kemampuan reproduksi dari hewan jantan dapat ditentukan oleh kualitas dan kuantitas semen yang dihasilkan. ${ }^{4}$

Spermatogenesis membutuhkan kerja stimulasi kedua hormon gonadotropin, yaitu LH (Luteinizing Hormone) dan FSH (Follicle Stimulating Hormone) berfungsi menstimulasi sel Leydig untuk memproduksi hormon testosteron di dalam testis. Sedangkan fungsi FSH (Follicle Stimulating Hormone), untuk menstimulasi sel sertoli dan memacu proses spermatogenesis. Hormon yang dapat menekan produksi spermatozoa, antara lain analog gonadotropine releasing hormone $(\mathrm{GnRH})$, hormon-hormon seperti progestin dan estrogen. ${ }^{5}$ Selain faktor hormonal, faktor eksternal lain yang dapat menekan proses spermatogenesis adalah stres. Stres adalah gangguan yang dialami oleh tubuh akibat stimulus yang berasal dari luar maupun dari dalam tubuh sendiri, dan akan menganggu equilibrium (homeostasis) fisiologi normal. ${ }^{6,7}$ selain manusia, hewan termasuk mencit merupakan salah satu mahluk hidup yang mudah mengalami stres. Stres pada mencit dapat diakibatkan oleh banyak faktor seperti perubahan habitat akibat adanya manipulasi paparan cahaya. ${ }^{7}$

Cahaya merupakan salah satu pemicu stres yang dapat mempengaruhi aktivitas reproduksi mencit. Serta berpengaruh terhadap kualitas spermatozoa. ${ }^{8}$

Kualitas spermatozoa sangat menentukan proses terjadinya pembuahan. Sel spermatozoa yang normal memiliki bagian kepala, leher, ekor dan harus mempunyai kondisi yang sehat dan bergerak cepat agar dapat menembus dinding sel telur. ${ }^{9}$

Cahaya juga memiliki efek terhadap proses maturasi organ kelamin mencit. Pada jantan maturasi seksual merupakan tahap dimana testis telah tumbuh dan berkembang serta mampu menghasilkan spermatozoa yang matang. ${ }^{8}$

\section{METODE PENELITIAN}

Penelitian ini adalah penelitian eksperimental dengan menggunakan rancangan acak lengkap (completely randomized). Penelitian dilakuan di Laboratorium Biologi Fakultas Kedokteran Universitas Sam Ratulangi Manado dengan rentang waktu sekitar bulan November 2012 samapi Desember 2012. Kriteria sampel terdiri dari inklusi dan eksklusi. Pada kriteria inklusi yaitu Tikus mencit jantan Mus musculus, Berusia 12-16 minggu, Berat badan 20-25 gram, Sehat, tingkah laku dan aktivitas mencit normal. Serta pada Kriteria eksklusi yaitu Tikus tampak sakit, tidak bergerak secara aktif, dan mati dalam penelitian. Sampel yang digunakan sebanyak 27 ekor mencit jantan.

\section{Prosedur Penelitian}

Kandang yang digunakan dalam penelitian ini, kandang pemeliharaan terbuat dari plastik yang memiliki tempat makan dan minum untuk hewan percobaan. Dasar kandang diberikan sekam. Kandang perlakuan berjumlah tiga, berukuran 36,5 $\mathrm{cm} \times 30 \mathrm{~cm} \times 23 \mathrm{~cm}$, yang terbuat dari kayu dan triplek.

Peralatan untuk melakukan pengamatan kualitas spermatozoa: Bilik hitung improved neubauer, stop watch, cawan petri, pipet tetes, gelas objek, gelas penutup, pinset, jarum pentul, kasa, counter (alat hitung), hot plate, kater, gunting bedah, mikroskop cahaya, Timbangan digital, Kamera digital untuk fotomikrografi.

Bahan Mencit (Mus musculus) jantan sebanyak 27 ekor, berusia 12-16 minggu dengan berat badan 20-25 gram. Makanan ternak untuk berikan pada mencit, Lampu, Bahan untuk pengamatan kualitas spermatozoa, Larutan $\mathrm{NaCl}$ 0,9\%, Metanol, giemsa $3 \%$, akuades. 
Perlakuan pemaparan cahaya lampu dilakuakan setelah hewan percobaan mengalami aklimatisasi selama satu minggu. Sebelum perlakuan dilakukan, hewan percobaan ditimbang terlebih dahulu untuk mengetahui berat badan awal dan kemudian hewan percobaan dimasukkan ke dalam kandang perlakuan. Perlakuan pemaparan cahaya lampu dilakukan setiap hari selama 30 hari. Dan pada hari ke-31 semua hewan percobaan akan dimatikan untuk selanjutnya dilakukan pengambilan sampel. Untuk pembagian perlakuan pemaparan cahaya lampu yaitu: Kandang kontrol tanpa pemaparan cahaya lampu, Kandang perlakuan I pemaparan cahaya 4 lampu ( 12 volt ), Kandang perlakuan II pemaparan cahaya 8 lampu ( 24 volt ). Mencit ditempatkan ke dalam masingmasing kelompok secara acak.

\section{Cara pengambilan sampel}

Hewan percobaan dibius dengan menggunakan Metanol dan kemudian dibedah menggunakan gunting untuk mengambil organ testis dan cauda epididimis. Kemudian organ testis beserta cauda epididimis diambil dan diletakkan kedalam cawan petri yang berisi $\mathrm{NaCl}$ 0,9\%. Cauda epididimis dipisahkan dengan cara memotong bagian proximal corpus epididimis dan bagian distal vas deferens. Selanjutnya cauda epididimis dimasukkan kedalam cawan petri yang berisi $1 \mathrm{ml} \mathrm{NaCl}$ $0,9 \%$, kemudian bagian proximal cauda dipotong sedikit dengan gunting lalu cauda ditekan dengan perlahan hingga sekresi cairan epididimis keluar dengan tersuspensi dengan $\mathrm{NaCl}$ 0,9\%. Suspensi spermatozoa mencit dari cauda epididimis ini dapat digunakan untuk pengamatan kualitas spermatozoa yang meliputi konsentrasi, motilitas dan morfologi spermatozoa mencit.

\section{Cara kerja pembedahan}

Alat: Bilik hitung Improved Neubauer, Cawan petri, Mikroskop cahaya, Gelas objek, Gelas penutup, Counter/penghitung, Cairan pengencer, Pipet tetes.
Bahan: Larutan $\mathrm{NaCl}$ 0,9\%, Metanol, Giemsa 3\%, Akuades.

\section{Pengamatan motilitas sperma}

Suspensi spermatozoa diteteskan pada alat bantu bilik hitung Improved Neubauer dan diamati di bawah mikroskop perbesaran 400x gerakan-gerakan spermatozoa. Dilakukan penilaian kualitas spermatozoa berdasarkan motilitasnya dengan nilai 0 sampai 5 sebagai berikut: 0: spermatozoa tidak bergerak, 1: gerak berputar di tempat, 2: gerakan berayun atau melingkar, kurang dari 50\% spermatozoa motil bergerak progresif, dan tidak ada gelombang, 3: antara 50\% sampai $80 \%$ spermatozoa motil bergerak progresif dan menghasilkan gerakan masa, 4: pergerakan progresif yang gesit dan segera membentuk gelombang dengan 90\% spermatozoa motil, 5:gerakan yang sangat progresif, gelombang yang sangat cepat menunjukkan 100\% spermatozoa motil. Periksa 4-6 lapangan pandang untuk mendapat 100 spermatozoa secara berurutan yang kemudian diklasifikasi sehingga menghasilkan presentase setiap kategori motilitas.

\section{Pengamatan morfologi spermatozoa}

Suspensi spermatozoa diteteskan di atas gelas objek, dibuat preparat hapus dan dikeringkan di udara, Sediaan hapus difiksasi dengan metanol selama 3-5 menit, kemudian diwarnai dengan giemsa 3\% selama 45 menit, preparat dicuci dengan akuades dan dikeringkan, diamati dengan mikroskop perbesaran 40x10 kelainankelainan bentuk atau abnormalitas yang terlihat, dari 100 spermatozoa yang diamati, dihitung presentase sel normal dan abnormal, penilaian semen berdasarkan jumlah sel sperma bentuk abnormal adalah dalam satu lapang pandang mikroskopik dihitung semua sel, baik yang normal maupun yang abnormal. Setelah mendapatkan jumlah 100 sel, dapat disimpulkan berapa persen terdapat sel yang abnormal. Pada umumnya bila terlihat sel dengan bentuk abnormal yang primer berjumlah 20\% atau lebih maka kualitas semen itu 
dianggap jelek. Bila yang terlihat itu sel bentuk abnormal yang sekunder dan jumlahnya lebih dari 25\% atau lebih maka pembuatan sediaan lebih baik diulang.

\section{Perhitungan jumlah/konsentrasi}

Organ testis beserta epididimis sebelah kanan diambil. Cauda epididimis dipisahkan dengan cara memotong bagian proximal corpus epididimis dan bagian distal vas deferens, potongan cauda epididimis diambil dan dimasukkan ke dalam cawan petri yang telah diisi $1 \mathrm{ml}$ larutan $\mathrm{NaCl} 0.9 \%$ dengan suhu $37-40^{\circ} \mathrm{C}$, kemudian cauda epididimis dipotongpotong sampai halus dan diaduk dengan gelas pengaduk sampai terbentuk suspensi spermatozoa, ada cara lain dengan cara potongan cauda epididimis diletakan ke dalam cawan petri yang berisi $1 \mathrm{ml} \mathrm{NaCl}$ 0,9\%, kemudian bagian proximal cauda dipotong sedikit dengan gunting lalu cauda ditekan dengan perlahan hingga sekresi cairan epididimis keluar dan terbentuk suspensi spermatozoa, suspensi spermatozoa yang telah diperoleh terlebih dahulu dihomogenkan dengan cara digetarkan dengan tangan atau diaduk dengan hati-hati dengan gelas pengaduk, suspensi sperma dihisap sebanyak 0,005 $\mathrm{ml}$ ke dalam pipet hemositometer. Petunjuknya ialah bila semen itu telah masuk dalam pipet sampai tanda 1,01, kemudian ujung pipetnya ditutup dengan jari. Dengan demikian suspensi spermatozoa diencerkan 200 kali,
Gelas obyek improved neubauer yang berkotak-kotak telah ditutup dengan gelas penutupnya. Teteskan setetes suspensi sperma dari pipet, tepat pada pinggir gelas penutup biarkan 5 menit hingga cairan itu menyebar ke seluruh sudut gelas penutup, sperma yang terdapat dalam 5 kotak, yaitu 4 kotak ditengah dan 1 kotak di sudut dihitung dengan mempergunakan pembesaran 45 x 10, kepala-kepala spermatozoa yang terdapat dalam kotak dihitung, kepala-kepala spermatozoa yang terletak melintang garis atas dan kiri dihitung, sedangkan yang melintang garis kanan dan bawah tidak dihitung atau sebaliknya. Dalam hal ini perlu dijelaskan bahwa yang dihitung kepalanya meskipun ekornya terdapat di luar kotak, Jika dalam kelima kotak itu $=\mathrm{X}$ maka konsentrasi sperma ditentukan dengan menggunakan rumus $\mathrm{X} / 2 \times 10^{5}$ sperma/ml suspensi.

\section{Analisa Data}

Semua data yang diperoleh akan dianalisa menggunakan ANOVA dengan metode rancangan acak lengkap pada ketelitian 5\%. Kemudian untuk mengetahui beda nyata antar perlakuan yang dilakukan, dilanjutkan dengan uji Bonferroni Multiple Range Test (DMRT). Semua analisa data dilakukan dengan menggunakan SPSS sofware for windows.

\section{HASIL}

Tabel 1. Rerata Motilitas Normal Spermatozoa antara kelompok kontrol (n=9) dan kelompok perlakuan $(\mathrm{n}=9)$

\begin{tabular}{ccccc}
\hline $\begin{array}{c}\text { Kelompok } \\
\text { subjek }\end{array}$ & N & $\begin{array}{c}\text { Rerata motilitas normal } \\
\text { spermatozoa ( \%) }\end{array}$ & F & P \\
\hline Kontrol & 9 & 82,77 & & \\
Perlakuan 1 & 9 & 73,66 & 153,660 & 0,000 \\
Perlakuan 2 & 9 & 64,33 & & \\
\hline
\end{tabular}


Tabel 2. Rerata Motilitas Abormal Spermatozoa antara kelompok kontrol (n=9) dan kelompok perlakuan $(\mathrm{n}=9)$

\begin{tabular}{ccccc}
\hline $\begin{array}{c}\text { Kelompok } \\
\text { subjek }\end{array}$ & N & $\begin{array}{c}\text { Rerata motilitas } \\
\text { abnormal spermatozoa } \\
\text { \% ) }\end{array}$ & F & P \\
\hline Kontrol & 9 & 17,22 & & \\
Perlakuan 1 & 9 & 25,22 & 119,129 & 0,000 \\
Perlakuan 2 & 9 & 35,66 & & \\
\hline
\end{tabular}

Tabel 3. Rerata Morfologi Normal Spermatozoa antara kelompok kontrol (n=9) dan kelompok perlakuan $(\mathrm{n}=9)$

\begin{tabular}{ccccc}
\hline $\begin{array}{c}\text { Kelompok } \\
\text { subjek }\end{array}$ & n & $\begin{array}{c}\text { Rerata morfologi } \\
\text { normal spermatozoa } \\
\text { \% ) }\end{array}$ & F & P \\
\hline Kontrol & 9 & 57,11 & & \\
Perlakuan 1 & 9 & 46,22 & 70,864 & 0,000 \\
Perlakuan 2 & 9 & 37,55 & & \\
\hline
\end{tabular}

Tabel 4. Rerata Morfologi Abnormal Spermatozoa antara kelompok kontrol (n=9) dan kelompok perlakuan $(\mathrm{n}=9)$

\begin{tabular}{|c|c|c|c|c|}
\hline $\begin{array}{c}\text { Kelompok } \\
\text { subjek }\end{array}$ & $\mathbf{n}$ & $\begin{array}{c}\text { Rerata morfologi } \\
\text { abnormal } \\
\text { spermatozoa } \\
(\%) \\
\end{array}$ & $\mathbf{F}$ & $\mathbf{P}$ \\
\hline Kontrol & 9 & 42,88 & \multirow{3}{*}{49,509} & \multirow{3}{*}{0,000} \\
\hline Perlakuan 1 & 9 & 52,66 & & \\
\hline Perlakuan 2 & 9 & 62,44 & & \\
\hline
\end{tabular}

Tabel 5. Rerata Konsentrasi Spermatozoa antara kelompok kontrol $(n=9)$ dan kelompok perlakuan $(n=9)$

\begin{tabular}{ccccc}
\hline $\begin{array}{c}\text { Kelompok } \\
\text { subjek }\end{array}$ & n & $\begin{array}{c}\text { Rerata konsentrasi } \\
\text { spermatozoa (x 10 } \\
\text { sperma/ml suspensi) }\end{array}$ & F & P \\
\hline Kontrol & 9 & 81,16 & & \\
Perlakuan 1 & 9 & 71,5 & 135,967 & 0,000 \\
Perlakuan 2 & 9 & 62,22 & & \\
\hline
\end{tabular}

\section{BAHASAN}

Dari penelitian yang telah dilakukan diperoleh hasil, didapatkan rata-rata kualitas spermatozoa mencit setelah pemaparan cahaya (lampu) berbeda antara kelompok kontrol dan kelompok perlakuan. Berdasarkan analisis statistik, ada perbandingan yang signifikan yaitu penurunan kualitas spermatozoa (motilitas, konsentrasi, morfologi) antara kelompok kontrol dan kelompok perlakuan. WHO menyebutkan motilitas spermatozoa yang dianggap normal adalah apabila $50 \%$ atau lebih bergerak maju dengan lambat atau 25 
\% bergerak maju dengan cepat. ${ }^{10}$ Dari hasil perhitungan didapatkan pada tabel IV.1 dan IV.2 bahwa kecepatan gerak spermatozoa terdapat perbedaan antara kelompok kontrol dan kelompok perlakuan. Pada kelompok kontrol tanpa pemberian lampu didapatkan rerata motilitas 82,77, pada kelompok perlakuan 1 dengan menggunakan 4 lampu didapatkan rerata molilitas 73,66, sedangkan pada perlakuan 2 didapatkan rerata motilitas 64,33. Dapat diartikan pada kelompok dengan perlakuan menggunakan 4 lampu gerak spermatozoa lebih lambat jika dibandingkan dengan kelompok kontrol, begitupun pada kelompok perlakuan dengan menggunakan 8 lampu dimana gerak spermatozoa akan semakin lebih lambat. Hal ini mungkin disebabkan karena mencit pada kelompok perlakuan mengalami penurunan spermatozoa yang semakin bertambah jika semakin tinggi aplikasi cahaya yang dipancarkan sehingga berpengaruh terhadap kualitas spermatozoa. Hasil penelitian ini sesuai dengan penelitian yang dilakukan Wilda Chusnia yaitu pada perlakukan pada 1 mencit menggunakan 1 lampu dan pada perlakuan pada 2 mencit menggunakan 2 lampu bahwa didapat perbedaan signifikan antara kecepatan motilitas spermatozoa pada kelompok kontrol dengan kelompok perlakuan. ${ }^{8}$

Motilitas akan berlangsung dengan baik bila ditopang oleh banyak hal diantaranya adalah morfologi dari spermatozoa itu sendiri. Morfologi yang baik adalah kepala bentuk oval dengan ukuran normal, ekor tidak melingkar ataupun ganda. ${ }^{10}$ Pada tabel IV.3 dan IV.4 dapat dilihat rerata morfologi pada kelompok kontrol didapatkan 42,88, dan pada kelompok perlakuan 1 dengan menggunakan 4 lampu didapatkan 52,66 sedangkan kelompok 2 dengan menggunakan 8 lampu didapatkan 62,44, rerata menunjukkan bahwa spermatozoa mencit mengalami perubahan morfologi, spermatozoa itu sendiri setelah diberikan perlakuan pemaparan cahaya (lampu), dari kelompok kontrol dapat dilihat perbandingan antara kelompok perlakuan dimana terjadi peningkatan jumlah morfologi abnormal spermatozoa.

Pada tabel IV.5 dapat dilihat perbedaan rata-rata konsentrasi spermatozoa pada kelompok kontrol 81,16, pada kelompok perlakuan 1 dengan menggunakan 4 lampu didapatkan rerata konsentrasi 71,5, sedangkan pada perlakuan 2 didapatkan rerata konsentrasi 62,22.

Secara keseluruhan stres merupakan salah satu penyebab menurunnya kualitas spermatozoa mencit. Cahaya sebagai bentuk stres fisik dan psikologis pada mencit mengaktifkan respon sentral dan perifer sistem endokrin. Aktivasi sistem endokrin sumbu Hipotalamus-HipofisisAdrenal melibatkan neurohormon $\mathrm{cRH}$ menuju GnRH dan mengganggu aktivitas kelenjar adenohipofise untuk menghasilkan FSH dan LH yang menurun. Stres psikologis pada mencit dapat menimbulkan hambatan pada tingkat hipotalamus dan menyebabkan gangguan hormonal sehingga mengakibatkan terjadinya kegagalan pada sel Leydig dalam mensekresi hormon testosteron. $^{11}$

\section{SIMPULAN}

Pemaparan cahaya lampu dapat menimbulkan stres pada mencit (Mus Musculus L) sehingga mempengaruhi kualitas spermatozoa dalam hal ini motilitas, konsentrasi dan morfologi. Semakin tinggi aplikasi cahaya maka kualitas spermatozoa mencit semakin menurun secara signifikan antara kelompok kontrol dan kelompok perlakuan.

\section{UCAPAN TERIMA KASIH}

Ucapan terima kasih disampaikan kepada Dr. dr. Lydia Tendean, MRepro, SpAnd, dan semua pihak yang baik secara langsung maupun tidak langsung telah menimbulkan ide atau gagasan dalam pemikiran penulis sehingga dapat menyelesaikan artikel ini. 


\section{DAFTAR PUSTAKA}

1. Tarigan RR. Motilitas, Imotilitas, Proses dan reaksi dalam Fertilisasi Sperma. Diunduh dari: http://blog.ub.ac.id/ranitarigan/2012/11/mo tilitas-imotilitas-proses-dan-reaksi-dalamfertilisasi-sperma/. Diakses 3 februari 2013.

2. Wongso AD. Oligozoospermia. Diunduh dari:

http://klinikandrologi.blogspot.com/2011/0 1/oligozoospermia.html. Diakses 29 januari 2013.

3. Wongso AD. Morfologi spermatozoa. Diunduh dari: http://klinikandrologi.blogspot.com/2008/0 7/morfologi-sperma-morfologi-yang.html. Diakses 3 februari 2013.

4. Hutabarat DK. Studi testosterone plasma kuantitas dan kualitas spermatozoa mencit (Mus musculus L.) setelah pemberian kombinasi hormone testosterone undekanoat (TU) dan ekstrak air blustru (Luffa aegyptica Roxb). Skripsi fakultas matematika dan ilmu pengetahuan alam. Universitas sumatera utara. Medan. 2011.

5. Rukmana RM. Pengaruh ekstrak daun belutas (pluchea indica less) terhadap proses spermatogenesis pada mencit (mus musculus). Jurusan iologi fakultas sains dan teknologi : Universitas islam negeri. 2010.

6. Anonymous. Definisi stres. Diunduh dari: http://repository.usu.ac.id/bitstream/123456
789/21565/4/ChapterII.pdf. Universitas sumatera utara. Diakses 28 oktober 2012

7. Gustini Yulisa. Teknik evaluasi aktivitas anti stres. Diunduh dari: file://C:/Users/user/Pictures/teknikevaluasi-aktivitas-anti-stress.html. Diakses 23 oktober 2012.

8. Chusnia wilda. Motilitas spermatozoa mencit. Diunduh dari: http://wildablog.blogspot.com/2011/11/mot ilitas-spermatozoa-mencit.html. Diakses 26 oktober 2012.

9. Hana A. Pengaruh cahaya terhadap aktivitas reproduksi tikus putih. Universitas Gadja Mada. Yogyakarta. 2000.

10. Khusna Aminaful, Herbianto Denny, Fatmawati Titi, Puspitasari Desi. Pengaruh warna cahaya terhadap diameter dan berat testis serta kualitas burung puyuh. Fakultas matematika dan ilmu pengetahuan alam. Universitas negeri semarang. 2011.

11. Kurniati R, Aryani $R$ dan Ibrahim S. Jumlah dan motilitas spermatozoa mencit (mus musculus l) Yang dipapari obat nyamuk elektrik berbahan aktif ( $d$ allethrin). Program studi biologi fmipa universitas mulawarman. Samarinda. Vol 10. 2011. No 2.

12. Harahap I. Pengaruh Kebisingan terhadap kuantitas dan kualitas spermatozoa tikus putih jantan dewasa (Rattus norvegicus). Fakultas Kedokteran Program Studi Ilmu Biomedik Pascasarjana Universitas Andalas. 2010. 